\title{
PROBLEMAS Y CONTRADICCIONES EN LA PROTECCIÓN DEL PRESTATARIO NO CONSUMIDOR EN LA LEY DE CONTRATOS DE CRÉDITO INMOBILIARIO
}

\author{
PROBLEMS AND CONTRADICTIONS REGARDING THE \\ PROTECTION OF NON CONSUMER BORROWER IN \\ THE CONTRACTS FOR REAL ESTATE CREDITS ACT
}

\author{
KLAUS JOCHEN ALBIEZ DOHRMANN*
}

Recibido: 22/07/2019

Aceptado: 31/08/2019

\begin{abstract}
SUMARIO: I. EL PRESTATARIO-PERSONA FÍSICA PRINCIPAL DESTINATARIO DE LA LCCI. II. PRESTATARIO CONSUMIDOR Y NO CONSUMIDOR. III. ¿TRATAMIENTO IGUAL DEL PRESTATARIO-PERSONA FÍSICA? IV. AHONDANDO EN LA NECESIDAD DE UN TRATAMIENTO DIFERENCIADO. V. LA INTERPRETACIÓN CONFORME CON LA DIRECTIVA 2014/17/UE. VI. LA «IMPERATIVIDAD» ABSOLUTA DE ALGUNAS NORMAS DE LA LCCI. VII. CUESTIONES CONCRETAS. 1. Inmuebles no residenciales o «sin función doméstica» hipotecados o gravados mediante otro derecho real de garantía. 2. Los préstamos inmobiliarios e hipotecarios mixtos o de doble finalidad. 3. Préstamos inmobiliarios con garantía hipotecaria u otro derecho real de garantía sobre una vivienda y otro inmueble con fines no domésticos. 4. Hipotecante no deudor que garantiza un préstamo inmobiliario. 5. Fiador y otros garantes personales. 6. Cambio de destino del inmueble residencial hipotecado sujeto a autorización del prestamista. VIII. DIFERENCIAS A NIVEL AUTONÓMICO. 1. Consideración general. 2. Normativa administrativa autonómica. 3. Normativa civil autonómica. IX. DERECHO TRANSITORIO. X. UNA ÚLTIMA CONSIDERACIÓN.
\end{abstract}

SUMMARY: I. THE PHYSICAL PERSON BORROWER AS MAIN RECEIVER OF THE CONTRACTS FOR REAL ESTATE CREDIT ACT. II. CONSUMER BORROWER AND NON CONSUMER BORROWER. III. SHOULD PHYSICAL PERSON BORROWER BE EQUALY TREATED? IV. DEEPING ABOUT THE NECESITY OF DIFERENCIATED TREATMENT. V. CONFORMING INTERPRETATION WITH DIRECTIVE 2014/17/EU. VI. SPECIFIC ISSUES. 1. Nonresidential real estate or real estate without household unction. 2. Real estate loans and loans for double function real estate (both household and non-household function). 3. Real estate loans with mortgage guarantee or an y other security right son real estate either for housing or non-housing function. 4. Nondebtor mortgage or ensuring real estate loans. 5. Bondsman and other personal guarantors. 6. Changing real estate function (from housing to non-housing function) needs creditor authorization. VIII. REGIONAL LEGAL DIFFERENCES. 1. General considerations. 2. Regional administrative law. 3. Regional civil law. IX. Transitional law. X. ONE LAST CONSIDERATION.

Resumen: Una de las principales novedades de la novísima Ley de contratos de crédito inmobiliario (LCCI), de 15 de marzo de 2019, es su clara vocación de potenciar la protección no sólo de las personas físicas que son consumidores sino también de las demás personas físicas que solicitan un préstamo hipotecario. La LCCI, que transpone parcialmente la Directiva 2014/17/UE, de 4 de febrero de 2014, va más allá de los mandatos de esta normativa europea, al extender el paraguas protector en la concesión de préstamos hipotecarios a cualquier prestatario que sea persona física. Esta protección 
tan amplia no está exenta de contradicciones y de problemas legales y prácticos que abordaremos en el presente trabajo.

Abstract: One of the main innovations from the Contracts for real estate credits Act ("LCCI", Ley de Contratos de Crédito Inmobiliario) of march 2019 is that it wants to protect not only consumers but also other physical persons who ask for a real estate credit. The "LCCI" partially transposes Directive 17/2014/EU of february 2014, but it goes beyond the contents of this Directives since it broadens the subjective protection: not only consumers but also other physical persons asking for real estate credits. This broader protection presents both contradictions and legal and practical problems that will be analyzed in this study.

Palabras clave: inmuebles de uso residencial, préstamos hipotecarios, tutela preventiva y tuitiva, prestatario, persona física, consumidor

Key words: housing function real estate, real estate credits, real estate loans, mortage loans, preventive guardianship, borrower, physical person, consumer

\section{EL PRESTATARIO-PERSONA FÍSICA PRINCIPAL DESTINATARIO DE LA LCCI}

Una de las principales novedades de la novísima Ley de contratos de crédito inmobiliario (LCCI), de 15 de marzo de 2019, es su clara vocación de potenciar la protección no sólo de las personas físicas que son consumidores sino también de las demás personas físicas que solicitan un préstamo hipotecario. La LCCI, que transpone parcialmente la Directiva 2014/17/UE, de 4 de febrero de 2014, va más allá de los mandatos de esta normativa europea, al extender, en principio, el paragua protector a cualquier prestatario que sea persona física. En comparación con otras leyes nacionales que transponen la Directiva, la LCCI es la que va más lejos en cuanto a los deudores de préstamos inmobiliarios que protege ${ }^{1}$. Esta Ley, según el art. 1-1, "tiene por objeto establecer determinadas normas de protección de las personas físicas que sean deudores, fiadores o garantes, de préstamos que estén garantizados mediante hipoteca u otro derecho real de garantía sobre bienes inmuebles de uso residencial o cuya finalidad sea adquirir o conservar derechos de propiedad sobre terrenos o inmuebles construidos o por construir". No obstante, la protección queda condicionada a que el bien inmueble sobre el que se constituye una hipoteca u otra garantía real sea residencial, quedando fuera del ámbito de aplicación los préstamos hipotecarios (o garantizados por otra

\footnotetext{
* Catedrático de Derecho civil de la Universidad de Granada. jalbiez@ugr.es.

${ }^{1}$ Pueden consultar ALBIEZ DOHRMANN, K. J. (2018), "Estudio comparado de la transposición de la Directiva 2013/17/UE del Parlamento y del Consejo Europeo, de 4 de febrero de 2014, sobre los contratos de crédito celebrados con consumidores para bienes inmuebles de uso residencial en algunos ordenamientos nacionales", Jornadas sobre la adaptación del Derecho español a la legislación y jurisprudencia en materia de créditos inmobiliarios, Registradores de España, Fundación Registral, pp. 39 y ss.
} 
garantía real) que se solicitan para la adquisición de bienes inmuebles que no tiene la consideración de residencial (principal, segunda residencia, cualquier inmueble que puede servir de residencia a una persona física).

A su vez, el legislador ha aprovechado esta Ley para mejorar, entre muchas otras leyes -en total trece-, la LCGC y el TRLGDCU en cuestiones relacionadas directamente con el control de las cláusulas abusivas ${ }^{2}$.

Al ser la LCCI una transposición parcial de la Directiva, el Gobierno ha considerado necesario desarrollarla -si bien sólo parcialmente- mediante el Real Decreto 309/2019, de 26 de abril, el cual ha entrado igualmente en vigor el 16 de junio de 2019, a excepción de algunas disposiciones concretas, que entraron en vigor al día siguiente de su publicación en el BOE. El mismo 16 de junio de 2019 entró en vigor la Orden ECE/482/2019, de 26 de abril, por la que se modifican la Orden EHA/1718/2010, de 11 de junio, y la Orden EHA/2899/2011, de 28 de octubre. En el Preámbulo de la LCCI se dice expresamente que "extiende su régimen jurídico a todas las personas físicas, con independencia de que sean o no consumidores". Continúa diciendo el Preámbulo que "esta ampliación de la esfera subjetiva de protección de la Ley frente a la Directiva sigue la línea tradicional de nuestro ordenamiento jurídico de ampliar el ámbito de protección a colectivos como los trabajadores autónomos”. Para que no se dude de esta realidad puesta de manifiesto por el Preámbulo, se cita expresamente la Orden EHA/2011, de 28 de octubre, de transparencia y protección del cliente de servicios bancarios, y más concretamente el capítulo II del título III (reformada por la Orden ECE/482/2019, de 26 de abril), siendo destinatario de esta Orden cualquier prestatario que sea persona física, si bien el capítulo se refiere exclusivamente a los préstamos hipotecarios de vivienda.

Escudarse en esta normativa administrativa para justificar la ampliación de la esfera subjetiva de protección en los préstamos hipotecarios, que es perfectamente legítima porque la Directiva 2014/17/UE es, salvo en lo referente a la FEIN y a la TAE, una normativa europea de mínimos, no resulta del todo exacto. Ciertamente, el capítulo II del título III de la Orden EHA/2011 regulaba el régimen de los créditos y préstamos hipotecarios que "será de aplicación a los servicios bancarios de crédito y préstamo hipotecario, en adelante préstamos, celebrados con un cliente, persona física, en los que la hipoteca recaiga sobre una vivienda o cuya finalidad sea adquirir o conservar derechos de propiedad sobre terrenos o edificios construidos o por construir" (con la reforma mediante la Orden ECE/482/2019, el título pasa a denominarse "Normas relativas a los créditos y préstamos inmobiliarios regulados por la Ley 5/2019, de 15 de marzo“). La parcial coincidencia de este precepto administrativo con los arts. 1-1 y 2.1,

\footnotetext{
2 Puede entenderse la postura crítica de VALERO FERNÁNDEZ-REYES, A. (2019) cuando afirma: ”La Directiva 93/13 y la Directiva 2014/17, si bien tienen un espacio de aplicación coincidente en determinadas cuestiones, se proyectan, realmente, en dos ámbitos distintos: uno general relativo a toda contratación con consumidores, cualquiera que sea el tipo de contrato, y otro particular, relativo a los contratos de préstamo hipotecario celebrados con consumidores (en España también con personas físicas no consumidoras, como veremos) en que la finca gravada es una vivienda (y otros inmuebles destinados a uso residencial o doméstico). Es por ello, que las normas sobre transparencia material y otras en que se pretende determinar criterios objetivos -e imperativos- de «abusividad», deberían haber sido adoptados, en aras a la seguridad jurídica, con un ámbito de aplicación general en materia de consumo, o, en caso contrario, haberse determinado claramente la normativa aplicable a cada uno de ellos, dado que el ámbito de la aplicación de la nueva Ley no agota los supuestos de préstamo hipotecario de consumo" ("La Ley de contratos de crédito inmobiliario: aspectos registrales y relacionados con la jurisprudencia del TJUE de 26 de marzo de 2019 sobre el vencimiento anticipado”, La Ley).
} 
letras a y b, LCCI se explica porque cuando se estaba redactando la Orden ministerial existía la Propuesta de Directiva sobre los contratos de crédito para bienes inmuebles de uso residencial [COM (2011) 142 final, 31.3.2011]. Con anterioridad estaba la Orden de 5 de mayo de 1994 sobre transparencia de las condiciones financieras de los préstamos hipotecarios en la que también con carácter general se refería a los prestatarios-personas físicas. Al ser una normativa administrativa, su eficacia protectora se reducía básicamente a los controles que pudiera realizar el Banco de España, pero sin una verdadera trascendencia en el orden sustantivo (apenas se conocen casos de nulidad de contratos de préstamos hipotecarios por incumplimiento de las normas de transparencia de la citada Orden). Con la Reforma de la Orden ministerial, el art. 19.1 queda redactado en los siguientes términos: "Este capítulo -se refiere al segundo capítulo- será de aplicación a las actividades realizadas por cualquier prestamista, intermediario de crédito o su representante que opere en España dirigidas o relacionadas con el diseño, el proceso de comercialización, la concesión, la gestión y el cumplimiento de los contratos de préstamo inmobiliario regulados en el artículo 2 de la Ley 2/2019, de 15 de marzo, reguladora de los contratos de préstamo inmobiliario”. Pero es ahora, con la LCCI ya en vigor, cuando se garantizará cumplidamente en el plano sustantivo, y por tanto no sólo en el plano administrativo, la transparencia informativa, documental y material que se debe cumplir en cualquier préstamo inmobiliario que esté comprendido en el art. 2.1, letras a y b. Los objetivos de la LCCI no se reducen sólo a garantizar la transparencia en la contratación de préstamos inmobiliarios sino que son mucho más amplios, si bien algunos, como veremos, no están dirigidos a los prestatarios que no son consumidores.

\section{PRESTATARIO CONSUMIDOR Y NO CONSUMIDOR}

La LCCI no define el consumidor, a diferencia del prestatario, el cual, según el art. 4-1), es "toda persona física que sea deudor de préstamos que estén garantizados mediante hipoteca u otro derecho real de garantía sobre bienes inmuebles de uso residencial o cuya finalidad sea la adquisición o conservación de terrenos o inmuebles construidos o por construir”. El prestatario-persona física puede ser o no consumidor. Esta delimitación subjetiva sigue siendo necesaria tanto en la aplicación de la LCCI como en la aplicación de otras leyes concurrentes. Por lo tanto, debemos saber qué se entiende por consumidor. La LCCI no ofrece ninguna pista. Podríamos pensar, en principio, que el concepto de consumidor es según la definición dada en el art. 3 TRLGDCU. Sin embargo, no es ésta la respuesta correcta. La respuesta la encontramos en la propia Directiva 2014/17/UE que, en lugar de definir el consumidor, remite a la Directiva 2008/48/CE. Conforme con el art. 4-1) de aquélla, es consumidor según "se define en el art. 3, letra a), de la Directiva 2008/48/CE”. La posición del legislador comunitario es totalmente coherente puesto que en una y otra Directiva se regulan contratos de crédito, en una el crédito inmobiliario y en la otra el crédito de consumo. En consecuencia, se debe partir del mismo concepto de consumidor. Además, la Directiva 2011/84/UE, de 25 de diciembre, sobre los derechos de los consumidores no modifica el concepto de consumidor de la Directiva 2008/83/UE. En consecuencia, según el art. 3, letra a), de la Directiva 2008/48/CE, es consumidor la persona física que, en las operaciones reguladas por la presente Directiva, actúa con fines que están al margen de su actividad comercial o profesional. Este mismo concepto es el que sigue la 
Directiva 2014/17/UE y, por tanto, también debe ser el mismo concepto en la LCCI ${ }^{3}$. Igualmente la Ley 2/2009, al definir el consumidor, dice que se es cuando "actúa en un ámbito ajeno a una actividad empresarial o profesional” (art. 1.1-2). El mismo significado sigue el Código de Consumo de Cataluña (cfr. art. 112-2, letra a). Como los Derechos nacionales transpuestos deben interpretarse también conforme con las directivas, la LCCI debe interpretarse según la Directiva 2014/17/UE. En pro de la congruencia que requiere la aplicación de normas concurrentes, se debe defender el mismo concepto de consumidor en la Ley 2/2009, de 31 de marzo (actuar en un ámbito ajeno a su actividad empresarial o profesional), que no ha sido derogada por la LCCI (con la singularidad de que en la Ley 2/2009 el consumidor puede ser persona jurídica, como también en el TRLGDCU).

Según el art. 2.1 de la Ley Crédito al Consumo (LCC), de conformidad con la Directiva 2008/48/CE, "se entenderá por consumidor la persona física que, en las relaciones contractuales reguladas por esta Ley, actúa con fines que están al margen de su actividad comercial o profesional”. Es la misma definición de la Directiva 87/102/CEE y de la LCC anterior, de 1995. La definición que se da del consumidor coincide con la que figuraba en el TRLGDCU (art. 3) antes de que fuese reformado por la Directiva 2011/84/UE. Sin embargo, el art. 3 TRLGDCU en su nueva redacción dice que "a efectos de esta norma y sin perjuicio de lo dispuesto expresamente en sus libros tercero y cuarto, son consumidores o usuarios las personas físicas que actúen con un propósito ajeno a su actividad comercial, empresarial, oficio o profesión”. El matiz entre una y otra normativa está en que el concepto de consumidor en los préstamos inmobiliarios se toma en consideración a factores funcionales -el préstamo que se pida debe ser ajeno a la actividad empresarial o profesional del prestatario-. En el TRLGDCU se atiende al propósito de quien adquiere un servicio o un bien, siendo consumidor el que interviene siendo su propósito ajeno a la actividad empresarial o profesional que desempeña. No es este el lugar para reflexionar sobre si realmente el concepto de consumidor del TRLGDCU es distinto del de siempre. Incluso se podrá decir que la discusión que pudiera darse puede resultar estéril en los préstamos inmobiliarios comprendidos en el art. 2. 1 letras a y b. Como dije en un primer momento, la figura del consumidor queda desdibujada, diluida, casi desparece, como ahora en la LCCI. Nociones tan frecuentes en el Derecho de consumo como consumidor medio o consumidor vulnerable pierden, en parte, su significado ${ }^{4}$. A partir de ahora quizá los operadores jurídicos deberán fijarse en el prestatario-persona física medio. Sin embargo, como se ha querido avistar más arriba, la cualidad de condición de consumidor puede tener su relevancia en cuestiones particulares.

El prestatario-persona física en un préstamo inmobiliario que no tiene la consideración de consumidor, necesariamente tiene que ser un emprendedor, un empresario individual, un comerciante, un profesional, un artesano o un trabajador autónomo por citar los sujetos económicos principales que intervienen en el mercado. En principio, aunque el prestatario-persona física desarrolle una actividad empresarial, comercial, profesional o artesanal tiene la tutela de la LCCI cuando el préstamo hipotecario está comprendido en el art. 2.1, letra a). No es este tampoco el lugar para

\footnotetext{
3 Así lo entiende también SÁENZ DE JUBERA HIGUERO, B. (2019), Los contratos de crédito inmobiliario tras la Ley 5/2019, de 15 de marzo, Tirant lo Blanch, p. 32.

${ }^{4}$ ALBIEZ DOHRMANN, K.J. (2018), “Algunas reflexiones básicas sobre el ámbito de aplicación de la futura regulación legal de los contratos de crédito inmobiliario”, Derecho privado, responsabilidad y consumo, dir. PÉREZ-SERRABONA GONZÁLEZ, J. L., Aranzadi, p. 86.
} 
definir cada una de las actividades económicas, pero en casos concretos habrá que precisar si el préstamo inmobiliario que se solicite por uno de estos sujetos económicos se hace con un fin al margen de su actividad o responde a esa actividad que desarrolla.

\section{III. ¿TRATAMIENTO IGUAL DEL PRESTATARIO-PERSONA FÍSICA?}

Con anterioridad al 16 de junio de 2019, los Bancos tenían el deber decumplir las normas de la Orden EHA/2011 que rigen "para los préstamos hipotecarios celebrados con un cliente, persona física, en los que la hipoteca recaiga sobre una vivienda o cuya finalidad sea adquirir o conservar derechos de propiedad sobre terrenos o edificios construidos o por construir" (en su nueva redacción remite expresamente al art. 2. 1 a y b LCCI). La transparencia documental que hasta entonces se exigía era la misma para cualquier prestatario-persona física. Muchos otros préstamos hipotecarios que son de fecha anterior a 2011 tenían que cumplir con la transparencia que exigía la Orden ministerial de 5 de mayo de 1994. Con la LCCI, cuando es de aplicación el art. 2.1, letra a, la información, la transparencia formal, documental y material son iguales para cualquier prestatario. Así, p. e., el test a que se refiere el art. 15.2 c LCCI es el mismo según la Circular del CGN 1/2009, de 24 de mayo, relativa a la Ley 5/2019, de 15 de marzo. Sin embargo, por lo que respecta al contenido de los préstamos inmobiliarios afectados por estas Órdenes ministeriales, los Bancos cuidaban en precisar el fin del préstamo hipotecario que se solicitaba para evitar, así, la aplicación del TRLGDCU, en particular el control de «abusividad» material, con la suerte, además, de que tampoco era posible el control de «abusividad» formal por mor de la jurisprudencia. Era común la siguiente cláusula: "La presente operación se formaliza al amparo del contrato marco de condiciones generales de financiación..., cuya finalidad es financiar las inversiones realizadas por autónomos...”. Con esta disposición predispuesta e impuesta por los Bancos, se dejaba fuera del control las cláusulas que fuesen abusivas formal y materialmente. Al margen del verdadero alcance de esta cláusula, habría que preguntarse si ahora con la LCCI esta cláusula tiene aún algún sentido. De todos es conocida la jurisprudencia que niega a los empresarios prestatarios la protección de la transparencia material, que, sin embargo, se concede -ahora por mandato legal-a los consumidores prestatarios, lo que resulta claramente asimétrico siendo las mismas cláusulas en unos y otros préstamos -el caso más paradigmático y grave son las cláusulas suelo- ${ }^{56}$. El control de las cláusulas materialmente abusivas, por otra parte,

\footnotetext{
5 Con la LCCI la cláusula suelo definitivamente queda enterrada, siendo nula en los préstamos hipotecarios inmobiliarios sujetos a la LCCI (vid. art. 21.3). A partir de la entrada en vigor de la Ley, los prestatarios - personas físicas que no son consumidores son los grandes beneficiarios porque hasta entonces se declaraban abusivas por falta de transparencia cuando el prestatario era un consumidor.

${ }^{6}$ Con la LCCI se añade un nuevo párrafo al art. 83 TRLGDU: "Las condiciones incorporadas de modo no transparente en los contratos en perjuicio de los consumidores serán nulas de pleno derecho” (vid. DF 8ª). Este párrafo es la consolidación de una codificación de la jurisprudencia que desde 2013 había admitido en nuestro ordenamiento jurídico un nuevo control de las cláusulas, esto es, el control de transparencia material o de «abusividad» formal de las cláusulas no negociadas en contratos con consumidores. También se incorpora una frase en el apartado cinco del art. 5 LCGC: "Las condiciones incorporadas de modo no transparente a los contratos en perjuicio de los consumidores serán nulas de pleno derecho" (vid. DF $4^{\text {a }}$ de la LCCI).

El control de transparencia material no se limita a las cláusulas esenciales sino que también es factible respecto de las cláusulas accesorias como ya lo dije con motivo del análisis de una Proposición de Ley, en "La protección de los empresarios en la Propuesta de Ley «De impulso de la transparencia en la
} 
queda reservado exclusivamente como consecuencia de los arts. 82 y ss. TRLGDCU a los préstamos inmobiliarios con consumidores.

Vale la pena traer a estas páginas la reciente STS 11 abril de 2019 (RJ 1364) en la que se niega al prestatario-persona física de un préstamo hipotecario de una vivienda y de un local de comercial la cualidad de consumidor aun cuando sea para una actividad profesional en el futuro (el préstamo hipotecario se concedió para montar un negocio de hostelería). EL TS comparte la tesis del Juzgado de Primera Instancia en contra del parecer de la Audiencia Provincial de Álava. El litigio trae causa de una acción individual de nulidad por el carácter abusivo de determinadas cláusulas abusivas: renuncia de la fiadora a los beneficios de orden, división y excusión; el pacto de liquidez; el interés de demora (17,5 \% anual); el vencimiento anticipado y la cláusula de gastos. Son interesantes las consideraciones del TS sobre lo que se debe entender por empresario o comerciante individual. La sentencia recurrida, además de considerar que la operación de préstamo se concertó en un marco ajeno a la actividad profesional de la demandada -era traductora-, aprecia que tampoco puede considerarse actividad empresarial, porque ella no tenía la cualidad legal de comerciante, conforme al art. 1 CCom; además, no tenía licencia fiscal o administrativa que amparase el ejercicio empresarial. A estos efectos, dicha circunstancia es, según el TS, irrelevante, dado que una misma persona puede ser considerada consumidora respecto de ciertas operaciones y operadora económica respecto de otras. Y, en segundo lugar, en nuestro Derecho, la cualidad de comerciante o empresario individual no deriva de la obtención de determinadas licencias o la superación de concretos requisitos administrativos. Al contrario, del art. 1 CCom se infiere que basta con el cumplimiento de dos requisitos no formales: tener capacidad y ejercer habitualmente la actividad; a los que la jurisprudencia, desde la conocida Sentencia de esta Sala de 25 de marzo de 1922, ha añadido el de actuar en nombre propio. Como estableció esta Sentencia, "el rol de comerciante viene delimitado por el dato puramente objetivo del ejercicio de actos de comercio". Y es claro que la explotación de una taberna o un bar supone un acto empresarial. Es decir, la calificación de una persona como empresario individual no se basa en un dato o requisito formal, sino en la realidad efectiva de los tres requisitos jurídico-materiales antes expuestos, aunque sea para el futuro. Que la prestataria tenga la profesión de traductora no impide que, simultáneamente, se dedique a una actividad empresarial, como es la explotación de un negocio de bar. Máxime cuando dicha simultaneidad no constituye prohibición o impedimento para el ejercicio del comercio, conforme con los arts. 13 y 14 CCom. Los argumentos dados en esta Sentencia tendrán el mismo valor ahora con la LCCI cuando el préstamo inmobiliario es subsumible en el art. 2.1, letra b, pero resulta irrelevante en los préstamos hipotecarios de la letra a) del mismo precepto. No obstante, si el prestamista quiere evitar que se apliquen los arts. 82 y ss. TRLGDCU le puede interesar una cláusula como la descrita más arriba. La posible «abusividad» de la cláusula de renuncia del fiador a los beneficios de orden, división y excusión así como el pacto de liquidez, incluso ciertas cláusulas de gastos del caso de la STS 11 abril 2019, no podrían ser objeto de examen. Solo las cláusulas de vencimiento

contratación predispuesta». Una solución a medias”, Revista Lex Mercatoria, 2018, n 8, pp. 1 y ss. Por lo tanto, como precisa CÁMARA LAPUENTE, S. (2019), la restricción con que la jurisprudencia del Tribunal Supremo aplica el control de transparencia material sólo a elementos esenciales del contrato (así, explícitamente, en la STS 14 julio 2016; obiter dicta en muchas otras) está llamada a cambiar, en "La transparencia en la Ley 5/2019, de contratos de crédito inmobiliario. Primeros apuntes”, La Ley, versión 27/03/2019, p. 9. 
anticipado y de interés de demora -que según los arts. 24 y 25 LCCI serían meras cláusulas declarativas si transcriben su contenido- así como determinadas cláusulas de gastos -las previstas en el art. 14 LCCI- tendrían las mismas consecuencias -la nulidad absoluta per se si no se cumplen las normas de la LCCI, sea el prestatario-persona física consumidor o no.

Al igual que la Orden EHA/2011, la LCCI excluye a las personas jurídicas y a las entidades sin personalidad jurídica incluso siendo consumidores. Los Bancos no están obligados a dispensar la misma protección aunque sería deseable que la transparencia fuese del mismo nivel, en beneficio de las propias entidades bancarias. Al menos si son consumidores están protegidas por el TRLGDCU.

La protección por igual de cualquier prestatario-persona física de un préstamo inmobiliario ex artículo 2.1, letra a, LCCI no sólo comprende la fase precontractualtransparencia informativa, documental y material-, sino que se extiende al contenido del contrato de préstamo, especialmente encuestiones tan importantes como las cláusulas deinterés variable, de interés de demora y de vencimiento anticipado, así como el derecho de reembolso anticipado. Las normas que las regulan son de naturaleza imperativa absoluta. Las cláusulas contrarias a las normas imperativas son nulas por ilegales pero no por abusivas. No hay, como en las cláusulas abusivas, un control de contenido. Simplemente el legislador puede disponer que determinadas cláusulas son nulas por no ajustarse a lo establecido previamente por la ley (así, entre otros, los arts. 24 y 25) LCCI). Sin embargo, muchas otras cláusulas financieras sólo serán, en su caso, objeto de un control formal y material al amparo del TRLGDCU. Es entonces cuando adquiere sentido la diferenciación entre prestatario consumidor y no consumidor. Para que los Bancos no se vean obligados a demostrar que el cliente no es un consumidor podrán insertar, como antes, la oportuna cláusula según la cual la financiación responde a una finalidad estrictamente empresarial, comercial o profesional. En ningún caso, serían de aplicación por analogía, según la jurisprudencia dominante, los arts. 82 y ss. TRLGDCU. De ahí, el posible interés de los Bancos en precisar también ahora, mediante la cláusula correspondiente, si el cliente pide un préstamo ajeno o no a su actividad profesional o empresarial.

Es significativo, especialmente si tenemos presente la jurisprudencia desarrollada en torno a la transparencia material de las cláusulas, conforme con el nuevo párrafo añadido al art. 83 TRLGDCU por la DF 8 a LCCI, según el cual "las condiciones incorporadas de modo transparente en los contratos en perjuicio de los consumidores serán nulas de pleno derecho". En los mismos términos se redacta el art. 5.5 LCGC, que ha sido modificado por la DF $4^{\text {a }}$ LCCI. El legislador ha codificado, pues, la jurisprudencia de la transparencia material en las cláusulas no negociadas para cualquier contrato con consumidores, pero mantiene el "veto" de este mismo control a las condiciones generales entre empresarios. Esta voluntad clara del legislador seguirá impidiendo en el futuro un cambio en la jurisprudencia a favor de la transparencia material de las condiciones generales en contratos con empresarios. Una razón más para que los Bancos cuiden en su clausulado que el préstamo que se solicite es para una actividad profesional o empresarial si no quieren verse obligados a demostrar que el cliente no es consumidor.

La diferenciación entre consumidor y no consumidor se exigirá, en su caso, en el control notarial y registral de los préstamos inmobiliarios sujetos a la LCCI. La LCCI no exime al Notario de advertir al prestatario-consumidor de la existencia de cláusulas abusivas en el préstamo inmobiliario. Su función no descansa exclusivamente en el 
cumplimiento del art. 15 LCCI. Esta advertencia podría tener lugar en el momento del asesoramiento del Notario al cliente o en la misma escritura de préstamo hipotecario, denegando, en su caso, la autorización de la misma. Sin embargo, no procede esta advertencia en el acta de información precontractual (cfr. el contenido del test a que se refiere el art. 15.2, según la Circular del CGN 1/2009, de 24 de mayo, relativa a la Ley 5/2019, de 15 de marzo). Esta advertencia no procede, sin embargo, si el prestatario es un empresario. Además, debe diferenciar si el prestatario es o no consumidor en la aplicación del art. 2.1, letra b. Una novedad es que los Registradores de la Propiedad no sólo han de consultar el Registro de las Condiciones Generales de la Contratación, sino que deben tener presente la jurisprudencia del Tribunal Supremo sobre cláusulas abusivas o contrarias a normas imperativas o prohibitivas. Esta novedad del art. 258.2 LH (cfr. DF $1^{\text {a }}$ LCCI) suscitará algunos problemas muy concretos que no podemos abordar aquí. Las cláusulas que sean ilegales o vulneran una norma prohibitiva, con independencia que sean negociadas o no, nunca deberían inscribirse, haya o no jurisprudencia. Las cláusulas son abusivas sólo si son declaradas por el TS como tales. Parece que el control registral en los términos del art. 258.2 LH abarca también las cláusulas que sean abusivas formalmente. Finalmente, señalar que el carácter general del nuevo apartado 4 del art. 521 LEC (incorporado por la DF $5^{\text {a }}$ LCCI) es de aplicación únicamente a los préstamos hipotecarios con consumidores, al disponer "que las sentencias firmes dictadas en acciones colectivas o individuales por las que se declare la nulidad, cesación o retractación en la utilización de condiciones generales abusivas se remitirán de oficio por el órgano judicial al Registro de las Condiciones Generales de la Contratación, para su inscripción”.

\section{AHONDANDO EN LA NECESIDAD DE UN TRATAMIENTO DIFERENCIADO}

La LCCI no sólo tiene por objeto los préstamos hipotecarios (art. 2.1a) sino también "la concesión de préstamos cuya finalidad sea adquirir o conservar derechos de propiedad sobre terrenos o inmuebles construidos o por construir siempre que el prestatario, el fiador o garante sea un consumidor (art. 2.1 b). Esta segunda norma es uno de los preceptos nítidos en los que el ámbito subjetivo queda limitado al prestatarioconsumidor. Necesariamente la norma se refiere al consumidor que sea persona física. Esta clara diferenciación con los préstamos cuya finalidad sea adquirir o conservar derechos de propiedad sobre terrenos o inmuebles construidos o por construir responde a la Directiva 2014/17UE, la cual incluye estos préstamos para su transposición a los Derechos nacionales. Con ello se pretende evitar la problemática que pudiera plantear la aplicación de esta previsión a los profesionales autónomos al no exigirse el carácter de uso residencial, lo que podría vincularse a contratos con fines exclusivamente profesionales $^{7}$. El art. 2.1, letra b, está pensando sobre todo en autopromociones o comunidades de bienes para construir una vivienda familiar, para transformar un local en vivienda ${ }^{8}$, para la rehabilitación de viviendas y edificios... Las mismas normas de transparencia informativa, documental y material en la fase precontractual de la LCCI rigen para estos préstamos inmobiliarios.

\footnotetext{
7 BERRROCAL LANZAROT, A. L. (2018). "Consideraciones generales en torno al proyecto de ley reguladora de los contratos de crédito inmobiliario", Actualidad civil, n. 1, p. 7.

${ }^{8}$ VALERO FERNÁNDEZ-REYES (2019).
} 
A lo largo del texto encontramos normas que limitan exclusivamente su ámbito de aplicación al consumidor.

a) La principal cláusula de los préstamos es la del interés remuneratorio. Para el caso de que esta cláusula se quisiera modificar hace falta un acuerdo entre las partes que se debe formalizar por escrito (art. 21.1-1 LCCIesta norma debe ser aplicada junto con el art. 8 del RD 309/2019-). Cuando el acuerdo mutuo es con un consumidor la variación del coste del préstamo se deberá ajustar, al alza o a la baja, a la de un índice de referencia objetivo, sin perjuicio de lo establecido en el art. 85.3 TRLGDCU y otras leyes complementarias según el RD 1/2007 (art. 21.1-2 LCCI). La protección que se otorga al consumidor no la tiene el prestatario no consumidor, lo que, en este caso, beneficia al prestamista, quien puede imponer un tipo de interés al margen de un índice de referencia objetivo.

b) El art. 25 LCCI establece un régimen imperativo de los intereses de demora para los préstamos o crédito concluido por una persona física que esté garantizado mediante hipoteca sobre bienes inmuebles para uso residencial. Aunque no lo dice explícitamente la norma, se debe entender que también quedan incluidos los préstamos para la adquisición de bienes inmuebles de uso residencial que estén garantizados mediante otra garantía real. Sin embargo, el régimen imperativo no alcanza a los préstamos inmobiliarios comprendidos en la letra b del apartado dos del art. 25. De modo que la cláusula de interés de demora se rige, en su caso, por el TRLGDCU y la LCCG o sólo por la LCGG.

c) En nuestro ordenamiento jurídico se regulan por primera vez los préstamos inmobiliarios en moneda extranjera (art. 20 LCCI), si bien limitados a los préstamos simples en divisa, cuyo régimen jurídico es principalmente de naturaleza imperativa cuando el prestatario es consumidor. Para garantizar una mayor transparencia, la Orden EHA/2899/2011, en su nueva redacción, exige a los prestamistas de préstamos inmobiliarios en moneda extranjera en cumplimiento del documento de liquidación ciertos deberes. Dispone expresamente el art. 20.6 LCCI que "el incumplimiento de cualquiera de las exigencias y requisitos previstos en este artículo determinarán, en favor del prestatario consumidor, la nulidad de las cláusulas multidivisa y permitirán al prestatario solicitar la modificación del contrato de modo tal que se considere que el préstamo fue concedido en la moneda en la que este percibierala parte principal de sus ingresos". Esta sanción no procede si el prestatario no es consumidor. No hace falta decir que la jurisprudencia europea (STJUE 20 septiembre 2017, Asunto c-186/16) y española (STS 15 noviembre 2017, RJ 4730; cfr. STS 31 octubre 2018, RJ 4881), que confirma la doctrina anterior) sobre cláusulas multidivisa abusivas queda reservada exclusivamente a favor del prestatario que sea consumidor y persona física (esta jurisprudencia rige también para las personas jurídicas y entidades sin personalidad jurídica que son consumidores). Por otra parte, los prestatarios que "no tengan la consideración de consumidores podrán pactar con su prestamista algún sistema delimitación del riesgo de tipo de cambio al que están expuestos en virtud del contrato de préstamo, en lugar del derecho reconocido en el apartado anterior" (art. 20.2 LCCI). Se podría fijar algún tipo de "techo" del tipo de conversión".

\footnotetext{
${ }^{9}$ SÁENZ DE JUBERA HIGUERO (2019), p. 223.
} 
d) La LCCI no ha derogado la Ley 2/2009, de 31 de marzo, por la que se regula la contratación con los consumidores de préstamos o créditos hipotecarios y de servicios de intermediación para la celebración de contratos de préstamo o crédito que se concierten con prestamistas profesionales que no son entidades financieras. Sólo modifica el art. 1 y da una nueva redacción al art. 5 . En definitiva, a los préstamos hipotecarios que no están sujetos a la LCCI pero en los que el prestatario es un consumidor les es de aplicación la Ley 2/2009. Los demás préstamos hipotecarios que no están comprendidos en esta Ley especial se regirán por otras disposiciones de carácter más general (LCGC, TRLGDCU).

\section{LA INTERPRETACIÓN CONFORME CON LA DIRECTIVA 2014/17/UE}

Se debe tener muy claro que además de que la LCCI va más allá de la Directiva 2014/17/UE, también regula muchas materias que nada tienen que ver con ella. Hay materias que son exclusivamente nacionales, domésticas, cuya regulación y solución corresponde exclusivamente al Derecho interno. Así, p. e., las normas reguladoras del interés variable, del vencimiento anticipado o del interés de demora no corresponden a una transposición de la Directiva 2014/17/UE. Tampoco tienen nada que ver con esta Directiva los arts. 5.5 y 83 en su nueva regulación por la LCCI. Son, como muchas otras, normas que resuelven cuestiones internas ajenas a la Directiva 2014/17/UE.

La LCCI no sólo transpone la Directiva 2014/17/UE sino que claramente va más allá en un tema tan importante cual es el ámbito de aplicación al tener como destinatario de los préstamos para la adquisición de bienes inmuebles de uso residencial y garantizados mediante hipoteca u otra garantía real a cualquier prestatario que sea persona física. Ahora bien, aunque en el Derecho interno la interpretación que se haga será, en principio, la misma para cualquier prestatario si las normas no distinguen, los operadores jurídicos no pueden interpretar las normas conforme con la Directiva 2014/17/UE más que cuando el prestatario es un consumidor o cuando son préstamos inmobiliarios con doble finalidad (cfr. Considerando 12 de la Directiva 2014/17/UE). Las cuestiones prejudiciales que puedan plantearse en relación con la misma sólo pueden y deben referirse a materias transpuestas en la LCCI y en las demás normas que la desarrollan. Así, cualquier problema de conformidad de la LCCI y de otras normas con la Directiva debe ceñirse a cuestiones en las que el prestatario es consumidor. Si el prestatario no es consumidor, las cuestiones que se susciten se deben resolver exclusivamente de acuerdo con las normas internas. En definitiva, a los efectos de la interpretación de las normas de la LCCI conforme con la Directiva 2014/17/UE hemos de separar claramente los dos ámbitos subjetivos, a saber, prestatario consumidor y prestatario no consumidor ${ }^{10}$. Ello no va a evitar, sin embargo, una contaminación «europea» a la hora de interpretar y aplicar la LCCI y demás normas complementarias en los que el prestatario no es consumidor (es un efecto mediato -casi inevitablecuando un Derecho nacional va más allá de una directiva).

\footnotetext{
${ }^{10}$ Sobre la interpretación de las normas nacionales que van más allá que la directiva que se transpone, vid. HABERSACK, M./ MAYER. C. (2015), "Die überschießende Umsetzung von Richtlinien”, Europäische Methodenlehre, ed. RIESENHUBER, K., $3^{\text {a }}$ ed., De Gruyter, pp. 309 y ss.
} 


\section{LA «IMPERATIVIDAD» ABSOLUTA DE ALGUNAS NORMAS DE LA LCCI}

Con carácter general, el art. 3-1 LCCI establece que "las disposiciones de esta ley y las contenidas en sus normas de desarrollo tendrá carácter imperativo, no siendo disponibles para las partes contratantes salvo que la norma expresamente establezca lo contrario". 1112

Algunas de las normas de la LCCI son absolutamente imperativas como las que expresamente determinan que «las reglas contenidas en un precepto no admiten pacto en contrario». Así lo establece el art. 24.2 para el vencimiento anticipado y el art. 25.2 para la cláusula de interés de demora (en este caso, limitado al supuesto del art. 2.1 a). También establece el art. 21.3 que "en las operaciones con tipo de interés variable no se podrá fijar un límite a la baja del tipo de interés”. Más el art. 21.4 dice rotundamente que "el interés remuneratorio en dichas operaciones no podrá ser negativo". Normas de este contenido no permiten ninguna cláusula de otro contenido -ni siquiera pactada- aun cuando ésta fuese beneficiosa para el prestatario. Las cláusulas que son contrarias a estas normas son ilegales (no abusivas). La consecuencia principal es que el Notario no debería en ningún caso autorizar las cláusulas ilegales o prohibidas. Si son cláusulas inscribibles, jamás deberían tener acceso al Registro de la Propiedad (cfr. RDGRN 10 noviembre 2015, RJ $6495^{13}$ ). Y los Tribunales tendrán que declarar, incluso de oficio, la nulidad de la cláusula al amparo del art. 6.3 CC. En los juicios ejecutivos hipotecarios, al menos en lo que respecta al vencimiento anticipado, la frase segunda del art. 693.2 LEC establece que "siempre que se trate de un préstamo o crédito concluido por una persona física y que esté garantizado mediante hipoteca sobre vivienda o cuya finalidad sea la adquisición de bienes inmuebles para uso residencial, se estará a lo que prescriben el artículo 24 de la Ley 5/2019, reguladora de los contratos de crédito inmobiliario y, en su caso, el artículo 129 bis de la Ley Hipotecaria”. Sin embargo, cabe preguntarse si se pueden oponer otras cláusulas ilegales por ser contrarias a la LCCI. Aunque no viene expresamente contemplado en la LEC, habría que entender que son oponibles, incluso deberían ser apreciadas de oficio. Si conforme con el art.695.1-4 ${ }^{\mathrm{a}}$ LEC se puede oponer el carácter abusivo de una cláusula contractual que constituya el fundamento de la ejecución o que hubiese determinado la cantidad exigible, no debería haber impedimento para oponer una cláusula ilegal en sede de este juicio. Esta no obstante evidente contradicción debería ser subsanada pronto por el legislador.

Que esta protección tan absoluta puede ser comprensible, especialmente en este sector financiero-financiación para la adquisición de bienes inmuebles de uso residencial, entre las cuales la más importante es la vivienda habitual- habida cuenta, además, de la desastrosa experiencia habida en España durante años, que no ha sido resuelta, ni siquiera mitigada, mediante medidas concretas, sobre todo medidas de

\footnotetext{
${ }^{11}$ Con carácter general, vid. ALVAREZ MORENO M ${ }^{\mathrm{a}} \mathrm{T}$. (2015), La protección jurídica del consumidor en la contratación en general (Normas imperativas y pactos al respecto), Ed. Reus.

${ }^{12}$ Una clara exposición sobre la declaración de la naturaleza imperativa de las normas de protección de los consumidores, vid. GARCÍA VICENTE, J. R. (2013), "La contratación con consumidores", en Tratado de contratos, dir. BERCOVITZ RODRÍGUEZ-CANO, B., tomo II, $2^{\mathrm{a}}$ ed., Tirant lo Blanch, pp. 1649 y ss.

${ }^{13}$ No obstante, señalar que el art. 251-6, número 4, letra a, del Código de Consumo de Cataluña, que se tuvo en cuenta en esta Resolución, ha sido declarado inconstitucional y ha sido anulado por la STC 54/2018, de 24 de mayo.
} 
naturaleza procesal (p. e., oponibilidad de las cláusulas abusivas en los procedimientos ejecutivos), que para algunos significa una excesiva socialización de la hipoteca. Ahora bien, esta protección tan absoluta en determinadas materias como las indicadas resulta un tanto desproporcionada cuando el prestatario no es un consumidor. Por una parte, resulta totalmente contradictorio que el prestatario no consumidor no puede acogerse a los arts. 82 y ss. TRLGDCU pero sí tiene a su favor la protección de determinadas normas que determinan el contenido de los préstamos hipotecarios inmobiliarios. Una de las muchísimas contradicciones que podemos encontrar en nuestro sistema contractual de condiciones generales. Por otra, al menos debería haberse admitido la negociación en estas materias entre la entidad financiera y el prestatario no consumidor. $\mathrm{O}$ al menos cuando las cláusulas resulten beneficiosas para el prestatario («imperatividad relativa»). Sin embargo, el carácter de «imperatividad absoluta» de las normas citadas no permite negociación alguna. ¿Por qué no se puede pactar una cláusula de vencimiento anticipado que puede interesar al prestatario no consumidor siempre que sea razonable y equilibrada? ¿Por qué una cláusula de vencimiento anticipado no puede regular el incumplimiento del prestatario en lugar del régimen resolutorio legal fijado imperativamente al menos cuando es resultado de un pacto? ¿Por qué no puede ser el interés de demora superior o inferior al fijado en el art. 25.1 a cambio de la reducción negociada de determinados costes de un préstamo hipotecario ex art. 2.1, letra a? El art. 25.1 no permite siquiera fijar un interés de demora inferior a tres puntos porcentuales del interés remuneratorio a lo largo del período en el que resulte exigible ${ }^{14}$. Con el art. 21.3 se borra de la faz de la tierra la cláusula suelo en los préstamos inmobiliarios sujetos a la LCCI. Pero, en principio, las cláusulas suelo, como también las cláusulas de vencimiento anticipado y de interés de demora, son perfectamente válidas en cualquier préstamo. Una decisión claramente política ha primado sobre consideraciones elementales del Derecho contractual.

\section{CUESTIONES CONCRETAS}

\section{Inmuebles no residenciales o «sin función doméstica» hipotecados o gravados mediante otro derecho real de garantía}

Todavía el APLCCI, de 26 de junio de 2016, se refería sin más a la «vivienda» como objeto de los préstamos hipotecarios sin precisar si debía ser residencial o habitual. Igualmente la Orden EHA/2899/2011 aludía sin más especificación a la vivienda. Con buen criterio, la LCCI y la Orden EHA/2899/2011 (en su nueva redacción) se ciñen a los términos de la Directiva 2014/17/UE, esto es, que los préstamos hipotecarios o garantizados mediante otro derecho real de garantía han de tener por objeto bienes inmuebles de uso residencial, siendo uno de los presupuestos de la nueva normativa. A estos efectos, precisa el art. 2.1, letra a, frase segunda, "también se entenderán como inmuebles para uso residencial aquellos elementos tales como trasteros, garajes, y cualesquiera otros que sin constituir vivienda como tal cumplen una función doméstica”. La principal conclusión de esta aclaración legal es que comprende cualquier inmueble, aunque no sea vivienda -primera, segunda, ocasional turística...para cuya adquisición se necesita un préstamo hipotecario con otra garantía real siempre que ese inmueble tenga una función doméstica. Por norma general, aunque el préstamo

${ }^{14}$ Criticado -con razón- por SÁENZ DE JUBERA HIGUERO (2019), p. 302. 
es único, a efectos de la garantía hipotecaria u otra garantía real habría que constituir el gravamen de modo individualizado sobre cada bien inmueble. Aunque resulta más extraordinario que se hipoteque sólo el trastero, una plaza de garaje u otra finca registral que pueda cumplir una función doméstica ${ }^{15}$. Pero precisamente para evitar dudas no parece mal esta norma aclaratoria ${ }^{16}$. Si bien, cabe precisar que la LCCI también va más allá, al menos si se entiende, como así es efectivamente, que bienes inmuebles no estrictamente residenciales pero sí con funciones domésticas están dentro de la ley.

Un supuesto concreto es la constitución de una hipoteca en garantía de un préstamo sobre un local de propiedad del prestatario. En principio, el local de negocio como objeto de una hipoteca o de otra garantía real quedaría claramente fuera del ámbito de aplicación de la LCCI ya que no tiene a priori una función doméstica. Lo mismo se puede decir de una nave industrial ${ }^{17}$. No obstante, cabría pensar que el local de negocio puede cumplir funciones domésticas (servir de almacén de cosas personales, de depósito personal de muebles de cualquier clase o de espacio de aparcamiento de vehículos particulares). Corresponde al prestatario probar en este caso que el local hipotecado cumple exclusiva o principalmente una función doméstica. Lo mismo se puede decir respecto de cualquier otro inmueble hipotecado que no cumple una función doméstica o no es preponderante esta función. El mismo planteamiento podemos hacer cuando se trata de bajeras (nombre que se da en la Rioja a locales y otros bajos de edificios).

\section{Los préstamos inmobiliarios e hipotecarios mixtos o de doble finalidad}

Sin entrar en el más que debatido tema de los préstamos hipotecarios mixtos para determinar la aplicación de las normas de consumo (me remito, principalmente, a la STS 5 abril 2017, RJ 2269, y a la STJUE 3 septiembre 2015, asunto C-110/14) ${ }^{18}$, nos tendríamos que plantear, no obstante, cómo se va a resolver este tema con la LCCI ya en vigor. Seguramente los conflictos serán menores por la protección práctica idéntica a los prestatarios-personas físicas ${ }^{19}$. Pero el problema no varía con la LCCI. Si el inmueble

\footnotetext{
15 En opinión de VALERO FERNÁNDEZ-REYES (2019) -que yo comparto- la LCCI “es aplicable a los préstamos y créditos que se garanticen con garajes y/o trasteros de forma aislada, es decir, sin comprender en la misma operación la hipoteca de una vivienda, siempre que su destino sea el uso doméstico tanto de su titular como de un posible arrendatario. No estarían comprendidos en su ámbito, sin embargo, el supuesto de plazas de garaje o solares con destino a un uso rotatorio de los aparcamientos (parking privado), o de locales o naves que se transforman en trasteros o almacenes para su alquiler o explotación mercantil con similar finalidad” (op. cit.).

16 Dudas que tiene ARROYO AMAYUELAS, E. (2017), en su acercamiento a la Directiva 2014/17/UE "La directiva 2014/17/UE sobre los contratos de crédito con consumidores para bienes de uso residencial”, Indret, con apoyo, además, en el Considerando 17 de la misma, p. 17. A su juicio, es una exclusión indeseable -que ya no lo es- que, además, no se correspondería con el Considerando 13, donde se afirma que la Directiva regula los contratos de de crédito relacionados de manera exclusiva o predominante con bienes de uso residencial, lo cual significa que otros bienes inmuebles también pueden entrar dentro del ámbito de aplicación de la norma (p. 18).

${ }^{17}$ De la misma opinión es SÁENZ DE JUBERA HIGUERO (2019), p. 42.

18 Por todos, SÁNCHEZ RUIZ DE VALDIVIA, I. (2018), "La condición de consumidor/a o empresario/a en los contratos con doble (o simple) finalidad y los controles de «abusividad» (contenido) y transparencia en la contratación entre empresarios/as”, Derecho privado, responsabilidad y consumo, dir. PÉREZ-SERRABONA GONZÁLEZ J.L., Aranzadi, en particular pp. 438 y ss.

19 Así, RODRÍGUEZ ACHÚTEGUI, E. (2017), “Algunas consideraciones sobre el anteproyecto de ley reguladora de contratos de crédito inmobiliario”, Aranzadi Doctrinal, nº 10, p. 26.
} 
hipotecado o gravado con otra garantía real objetivamente no está destinado con carácter preponderante a la residencia (es indiferente que sea principal o secundaria), aunque figure como tal en la escritura, la protección que dispensa la LCCI al prestatario no tendría razón de ser. Lo decisivo no es tanto el fin principal o predominante con la que se pide el préstamo hipotecario -para adquirir el inmueble de uso residencial o para realizar en él una actividad profesional-, como que el inmueble hipotecado ha de tener un uso residencial (total o preponderantemente), al menos hipotético. Conforme con este planteamiento, habría que precisar o modularla doctrina más reciente que toma en consideración sólo el fin predominante del préstamo hipotecario (así, la citada STS 5 de abril 2017).

El mismo criterio debería regir para los préstamos inmobiliarios mixtos sin garantía real que pueden responder a una doble finalidad, aunque en la práctica es difícil que se discuta sobre una doble finalidad de un préstamo inmobiliario (que yo sepa, al menos no ha habido casos judiciales).

\section{Préstamos inmobiliarios con garantía hipotecaria u otro derecho real de garantía sobre una vivienda y otro inmueble con fines no domésticos}

Por muchas razones, cuando se suscribe un préstamo con garantía hipotecaria, la escritura de otorgamiento es única aun cuando los bienes inmuebles hipotecarios son de distinta naturaleza. Con independencia de la necesaria individualización de la hipoteca sobre cada uno de los inmuebles hipotecados, cuando se trata de un préstamo hipotecario sujeto a la LCCI puede ser tenido en cuenta el carácter predominante del bien inmueble de uso residencial sobre los demás inmuebles que no cumplen ninguna función residencial -tanto en sede de la letra a y b del art. 2.1-. Pero también se puede estar al fin del contrato de préstamo. Podemos traer a colación la STS 11 abril 2019 (RJ 1364) que tiene por objeto un préstamo garantizado mediante una hipoteca sobre la vivienda y otra sobre un local de negocio. El TS llega a la conclusión de que el fin del préstamo hipotecario consistía en financiar una actividad comercial futura por lo que no son de aplicación los arts. 82 y ss. TRLGDCU.

\section{Hipotecante no deudor que garantiza un préstamo inmobiliario}

En lugar de que sea el prestatario el que dé en garantía hipotecaria un inmueble de uso residencial, puede garantizar el préstamo inmobiliario un tercero hipotecando un bien inmueble de uso residencial de su propiedad (hipotecante no deudor). El hipotecante no deudor ha de ser necesariamente persona física (cfr. art. 2.11 LCCI). Este préstamo hipotecario está sujeto igualmente a la LCCI, siendo, entonces, indiferente la condición del prestatario (p.e., si es persona jurídica; si ésta es consumidor o no $)^{20}$.

Surge la duda de si este préstamo hipotecario se rige por la LCCI cuando el fin del mismo es garantizar una actividad comercial o profesional. La respuesta debe ser afirmativa si el inmueble que se hipoteca es residencial, siendo, a estos efectos, indiferente el fin del préstamo. Por la vinculación de la hipoteca con el préstamo, el

\footnotetext{
20 A juicio de SÁENZ DE JUBERA HIGUERO (2019), no resulta exigible que siempre concurra un prestatario persona física para que se aplique la LCCI (pues no hay previsión a tal efecto, sino más bien al contrario), p. 39.
} 
préstamo en sí mismo está sujeto igualmente a la LCCI (especialmente relevante en cuestiones como la tasación del inmueble o la evaluación económica del hipotecante no deudor).

\section{Fiador y otros garantes personales}

Una de las singularidades de la LCCI es que la protección que otorga se extiende también al fiador y a otros garantes personales. Un requisito fundamental es que estos garantes sean personas físicas. Si el prestatario-persona física es consumidor, el garante, aun siendo empresario o comerciante, tiene la protección que le dispensa la LCCI. Habría que concretar qué normas concretas de la LCCI son realmente de aplicación, en especial las normas de información y de transparencia. La LCCI se refiere al prestatario, en particular en los arts. 14.1 y 15.1, pero esa misma información y transparencia deberían conocer los garantes del prestatario -personales y reales-. Ahora bien, tampoco tiene sentido que se exija siempre la misma información y transparencia que se debe dar al prestatario, debiéndose estar también a la información y transparencia que realmente se debe dar a los garantes para que conozcan y comprendan el riesgo que asumen antes de garantizar un préstamo inmobiliario (en este sentido, puede ser oportuna la RDGRN 17 julio 2017, RJ 3931).

Los garantes personales podrán hacer valer frente al prestamista aquellas normas imperativas que no admiten pactos sobre determinadas cláusulas (p. e., vencimiento anticipado o interés de demora) y, en su caso, las cláusulas que sean abusivas.

\section{Cambio de destino del inmueble residencial hipotecado sujeto a autorización del prestamista}

En un comentario mío de una cláusula concerniente al cambio de destino de la vivienda hipotecada negué, en contra del parecer del TS, que la misma fuese abusiva $^{2122}$. Me refiero a la STS 23 diciembre 2015 (RJ 5714) que declara el carácter abusivo de la cláusula según la cual "la parte prestataria deberá destinar el importe del préstamo, junto con los recursos propios que sean necesarios, a la adquisición onerosa de la vivienda que luego se describe, que constituye su residencia habitual”. A renglón seguido, "la parte prestataria declara que el bien hipotecado no está afecto a ninguna actividad profesional y se obliga a no variar su actual destino sin la autorización expresa y comunicada por escrito del Banco". El préstamo hipotecario tiene por objeto un inmueble destinado a residencia habitual. Por parte del prestatario hay un compromiso firme de destinar el dinero prestado a la adquisición del inmueble y también asume que no puede cambiar el destino del inmueble a un uso profesional si no es con la autorización y comunicación del Banco. La cláusula es, además, suficientemente clara para que el prestatario sepa a qué atenerse si tiene la intención de querer cambiar el destino. Es una predisposición que el Banco redacta en su propio interés pero también

\footnotetext{
${ }^{21}$ ALBIEZ DOHRMANN, K. J. (2016), "La clausula de autorización por el Banco del destino profesional de la vivienda residencial o habitual hipotecada (a propósito de la STS 23 diciembre 2015), Revista Lex Mercatoria, número 8, pp. 35 y ss.

${ }^{22}$ Del mismo parecer es DOMÍNGUEZ LUELMO, A. (2018) "La vivienda habitual y otros inmuebles en garantía del cumplimiento de las obligaciones del prestatario", Los contratos de crédito inmobiliario, dirs. ALBIEZ DOHRMANN, K. J. / MORENO-TORRES HERRERA, Mª L., Aranzadi, p. 1001.
} 
porque este préstamo hipotecario tiene un régimen legal propio. Muchas de las normas de este régimen legal son de naturaleza imperativa (normas sustantivas $\mathrm{y}$ administrativas) al que están sujetos ambas partes del contrato de préstamo hipotecario. De acuerdo con la normativa entonces vigente el prestatario pierde, desde luego, con el cambio de destino las ventajas que la protección "pro consumatore" le dispensa Al menos así lo puede entender el Banco. Si se autoriza expresamente el cambio, ciertamente quien se beneficia es la entidad bancaria. Pero para ello, habría que sustituir determinadas cláusulas por otras, novando objetivamente la escritura de préstamo hipotecario, lo que llevará consigo nuevos costes (notariales, registrales), sobre todo para el consumidor. El Banco puede informar debidamente antes de la autorización de las ventajas y desventajas del cambio de destino de la vivienda hipotecada. Eran algunas de las razones que alegué para defender la validez de la cláusula, aparte de denunciar la defectuosa fundamentación jurídica para justificar el carácter abusivo de la cláusula en cuestión.

Una de las novedades de la LCCI es que se puede pedir un préstamo para una actividad profesional o económica dando en garantía real un inmueble de uso residencial o que un tercero consienta la constitución de una garantía real de un inmueble de uso residencial (por norma general constituyendo una hipoteca). Si el inmueble deja de ser de uso residencial cambiando el destino, entonces desaparece uno de los requisitos básicos para la aplicación de la LCCI, esto es, el carácter residencial del inmueble hipotecado. La cláusula no negociada que exigiera no obstante la autorización del Banco al menos no sería desde luego abusiva si el prestatario no es un consumidor.

\section{DIFERENCIAS A NIVEL AUTONÓMICO}

\section{Consideración general}

La DA $5^{a}$ del Anteproyecto de la LCCI reconocía con carácter general la competencia de las Comunidades Autónomas para aprobar normas sobre las mismas materias, asumidas estatutariamente, pero, como se advirtió expresamente, en ningún caso podrán establecer un nivel de protección inferior a las que apruebe el Ministerio de Economía y Competitividad. Ya con anterioridad, el Consejo de Estado, en su Dictamen de 14 de febrero de 2008, hizo la siguiente observación: “Al hilo de algunas recientes reformas estatutarias, parece clara la pretensión de reafirmar un protagonismo cada vez mayor de las Comunidades Autónomas en el escenario europeo, lo cual, en lo relativo a la fase de incorporación de las normas comunitarias, se manifiesta en dos puntos concretos: relaciones bilaterales y transposición por las Comunidades Autónomas sin necesidad de una previa norma estatal básica”.

El art. 26.1 LCCI, que establece las fuentes jurídicas que son de aplicación, determina que son de aplicación, en primer lugar, esta ley y las disposiciones que la desarrollan, y, en segundo lugar, las disposiciones de las Comunidades Autónomas en el ejercicio de sus competencias.

La DA $5^{\text {a }}$ LCCI precisa ahora que "Sin perjuicio del desarrollo de la legislación básica estatal que realicen las Comunidades Autónomas en el ejercicio de las competencias asumidas estatutariamente, la información precontractual a facilitar a los prestatarios debe ser homogénea, en aras de la unidad de mercado, de tal forma que puedan valorar adecuadamente las diferencias entre unas ofertas y otras en todo el 
territorio español, por lo que la normativa autonómica deberá respetar los modelos normalizados de información que se establezcan por la normativa básica, y no podrá exigir adicionar documentación complementaria que pueda producir confusión en el prestatario y distorsione el objeto de la normativa básica de transparencia”.

Al menos en un tema tan capital de los préstamos inmobiliarios, cual es la información y la transparencia, debe haber la mayor coincidencia posible en beneficio de la unidad de mercado bancario y de sus principales protagonistas, los prestamistas y los prestatarios, aunque, en principio, no tienen competencia legislativa para ello.

\section{Normativa administrativa autonómica}

Todas las Comunidades Autónomas tienen en sus respectivos Estatutos competencia en materia de consumo y también tienen competencia, si así lo prevén sus Estatutos, para desarrollar las normas estatales para la ordenación del crédito y de la banca. Las normas autonómicas que se dicten sólo pueden establecer consecuencias puramente administrativas, sin perjuicio de sus consecuencias en el orden civil y penal que establezcan las normas estatales.

En Andalucía existe la Ley 3/2016, de 9 de junio, para la protección de las personas consumidoras y usuarias en la contratación de préstamos y créditos hipotecarios sobre la vivienda (cfr. los arts. 27, 58.2.4 ${ }^{\circ}$ y 75.2 del Estatuto andaluz). La Ley andaluza me parece en líneas generales técnicamente buena, además novedosa y acorde con el Derecho actual, tanto en su terminología como en su enfoque ${ }^{23}$. Otra cuestión es la constitucionalidad de algunos de sus preceptos y la eficacia real de la Ley. Más básica es la Ley madrileña 1/2012, de 26 de marzo, por la que se regula la contratación con los consumidores de préstamos o créditos hipotecarios y de servicios de intermediación para la celebración de contratos de préstamo o crédito. Esta Ley que fue recurrida ante el TC ha sido declarada parcialmente inconstitucional por la Sentencia 119/2018, de 31 de octubre ${ }^{24}$. Cabe objetar a los legisladores de las dos Comunidades Autónomas que se adelantaron con excesiva rapidez al legislador estatal, lo que ha producido discordancias entre una y otra legislación, en perjuicio, además, de la seguridad jurídica. Podemos llegar a tener diecisiete leyes autonómicas cuando sería preferible una buena normativa estatal en lugar de tantas leyes autonómicas, aunque no se puede negar que cada Comunidad Autónoma ejerza las competencias que les corresponda en esta materia. Aun así, en Alemania, que es un Estado Federal, el Gobierno Federal ha pedido en la Ley que transpone la Directiva 2014/17/UE que los Länder se abstengan de regular los créditos inmobiliarios en materias para los que son competentes, seguramente para evitar una ingente producción legislativa que no conduce a nada. La multiplicación de tantas normas desazona a cualquiera, y, en particular, a los operadores financieros y a los consumidores.

La duplicidad de normas nos lleva a la conclusión de que, en estos momentos, la Ley andaluza sólo protege a los prestatarios-consumidores de préstamos y créditos

\footnotetext{
${ }^{23}$ Por todos, LÓPEZ HERNÁNDEZ, C. V. (2018), "La regulación autonómica del crédito hipotecario: Ley 3/2016, de 9 de junio", Los contratos de crédito inmobiliario, dirs. ALBIEZ DOHRMANN K. J./ MORENO- TORRES HERRERA, M ${ }^{a}$ L., Aranzadi, pp. 217 y ss.

${ }^{24}$ Estima parcialmente el recurso de inconstitucionalidad y, en consecuencia, declara inconstitucionales y nulos los artículos 3 y 8 a) de la Ley 1/2012, de 26 de marzo, para la protección de los derechos de los consumidores mediante el fomento de la transparencia en la contratación hipotecaria en la Comunidad de Madrid.
} 
hipotecarios, de modo que las Autoridades andaluzas sólo pueden inspeccionar y controlar la actividad bancaria en este sector. Los demás préstamos inmobiliarios estarán sujetos a la normativa estatal (sobre las competencias sancionadoras del Estado y de las Comunidades autónomas vid. la DA 14 de la Ley 10/2013 y el art. 48 LCCI). Ello, sin perjuicio, de que la Comunidad Autónoma de Andalucía ampliara la protección de los prestatarios mediante la oportuna Reforma de la Ley 3/2016, de 9 de junio.

\section{Normativa civil autonómica}

Algunas Comunidades Autónomas regulan directamente las relaciones jurídicas entre empresarios y consumidores, sin que se tenga muy claro si tienen competencia para ello, habida cuenta de que el Derecho civil autonómico (cfr. art. 149.1-8 ${ }^{\mathrm{a}}$ CE) no se identifica con el Derecho autonómico de consumo, y el Derecho mercantil es de competencia exclusiva del Estado (cfr. art. 149.1-6 ${ }^{\text {a }} \mathrm{CE}$ ). Un paradigma es el Código de Consumo de Cataluña, el cual tiene su base en el art. 123 del Estatuto catalán, el cual se reserva la competencia exclusiva en materia de consumo. Pero la Constitución no contiene ninguna norma que permita que una Comunidad Autónoma pueda atribuirse exclusivamente las materias de consumo. La competencia del desarrollo del Derecho de consumo puede venir también directamente de la obligación que tienen las Comunidades Autónomas de transponer las directivas siempre que la materia comunitaria sea igualmente competencia autonómica. Cataluña, una vez más, se ha adelantado al Estado español al aprobar mediante la Ley 20/2014, de 29 de diciembre, para la mejora de protección de las personas consumadoras en materia de créditos y préstamos hipotecarios, vulnerabilidad económica y relaciones de consumo (vid. arts. 261- 1 y ss.) ${ }^{25}$. En el Preámbulo se justifica, en parte, la aprobación de la Ley 20/2014, siguiendo orientaciones marcadas por varios proyectos comunitarios sobre la materia que regula, p. e., la Directiva 2014/17/UE. La principal justificación de esta Ley reside, según la misma, en los arts. 123, 120.2 y 126.3 del Estatuto de Cataluña. La Ley 20/2014 fue recurrida parcialmente ante el TC que declaró inconstitucional algunos preceptos en la Sentencia 54/2018, de 24 de mayo ${ }^{26}$.

\footnotetext{
${ }^{25}$ Vid. NASARRE AZNAR, S./ SIMÓN MORENO, H. (2015), "Un paso más en la protección de los deudores hipotecarios de vivienda: La Directiva 2014/17/UE y la Reforma del Código de Consumo de Cataluña por Ley 20/2014”, $R D B B, \mathrm{n}^{\circ} 139$, pp. 11 y ss.; una lectura desde el punto de vista notarial ofrece ESQUIROL JIMÉNEZ, V. (2015), "La nueva regulación de los créditos y préstamos hipotecarios en el Código de consumo de Cataluña”, RJC, pp. 743 y ss.

${ }^{26}$ Se declara la inconstitucionalidad y nulidad, en cuanto resultan aplicables a los sectores energéticos del gas y la electricidad, de los siguientes artículos: 17, por cuanto añade al artículo 252-4 del Código de consumo de Cataluña el apartado séptimo, en sus párrafos primero, segundo inciso («si no se ha presentado el informe... que se había solicitado») y tercero, y el apartado octavo; y 18.2, por cuanto modifica el apartado sexto del artículo 252-5 de la letra a) Ley 22/2010 (LCAT 2010, 507), en los siguientes incisos: «que existan, como mínimo, dos recibos o facturas impagados sobre los que no exista ninguna reclamación pendiente de resolución, siempre que no hayan sido objeto de reclamación por la persona consumidora» e «y que se le haya dado un plazo no inferior a diez días hábiles para pagarlos».

Declarar la inconstitucionalidad y nulidad de los siguientes artículos: 8, por cuanto añade un nuevo apartado tercero al artículo 132-4 de la letra b) Ley 22/2010 (LCAT 2010, 507), en los incisos «0 demanda judicial» $\mathrm{y}$ «o a la demanda judicial»; 13, por cuanto añade un nuevo apartado cuarto al artículo 251-6 de la Ley 22/2010 (LCAT 2010, 507) ]; y 20, por cuanto añade un nuevo apartado segundo al artículo 262-6, y un nuevo apartado cuarto al artículo 263-2 de la Ley 22/2010 (LCAT 2010, 507) .
} 
Según el art. 262-2 del Código de Consumo catalán: “1. Los preceptos del presente título se aplican a las relaciones de consumo en materia de créditos y préstamos garantizados con una hipoteca sobre la vivienda, tanto si son destinados a su adquisición como a su rehabilitación o a la rehabilitación del inmueble del que forma parte. 2. Los preceptos del presente título relativos a las personas consumidoras en contratos de crédito o préstamo hipotecario se aplican también a los avalistas de la operación de crédito o préstamo y, si procede, a los propietarios hipotecantes. 3. Los preceptos del presente título se entienden sin perjuicio de las obligaciones establecidas por las demás normas que regulan esta materia, siempre y cuando sean más beneficiosas para las personas consumidoras, y por la legislación básica del Estado”. No están sujetos a la normativa catalana los préstamos hipotecarios en los que el prestatario no es consumidor pero es persona física, siendo de aplicación principal la LCCI y demás normas que la desarrollan. Tampoco están sujetos al Código de Consumo de Cataluña los préstamos inmobiliarios con otra garantía real, con independencia de que el prestatario sea consumidor o no. El legislador catalán tendrá que preguntarse por la oportunidad de una reforma de la Ley 20/2014, de 29 de septiembre, o si considera preferible que sea de aplicación la LCCI en aquellas materias que no están reguladas por el Código de Consumo catalán.

\section{DERECHO TRANSITORIO}

La LCCI proclama la irretroactividad absoluta (DT 1 $1^{\mathrm{a}}$, apartado uno), con lo cual los contratos de préstamos suscritos con anterioridad a la entrada en vigor de la Ley se rigen por las normas entonces aplicables. Ni siquiera, según la Exposición de Motivos, deba servir la LCCI como parámetro comparativo -una advertencia poco afortunada porque pretende condicionar a quienes tienen que interpretar y aplicar las leyes-. Son decenas de miles de préstamos inmobiliarios -sobre todo hipotecarios- que por su larga duración - diez, veinte o treinta años- van a estar sometidos a la legislación anterior, salvo en los supuestos concretos previstos en los apartados dos, tres y cuarto de la DT $1^{\text {a }}$.

Particularmente significativas van a ser las cuestiones que vaya a plantear la cláusula de vencimiento anticipado en los procedimientos ejecutivos de préstamos hipotecarios nacidos al amparo de la legislación según el vencimiento se haya producido antes o después del 16 de junio de 2019 (cfr. DT 1ª, ap. 4). Si se produce antes, habrá que diferenciar claramente entre el vencimiento anticipado de un préstamo inmobiliario concertado con un consumidor -éste puede alegar, en su caso, el carácter abusivo de la cláusula o puede apreciarse de oficio- o con un prestatario que no es consumidor -no puede oponer la «abusividad» de la cláusula. Sobre esta cuestión es muy ilustrativa la STS 11 septiembre 2019 que en un "obiter dicta" afirma en el apartado once del fundamento jurídico octavo que "procede aplicar las siguientes pautas u orientaciones jurisprudenciales a los procedimientos de ejecución hipotecaria en curso, en los que no se haya producido todavía la entrega de la posesión al adquirente:

a) Los procesos en que, con anterioridad a la entrada en vigor de la Ley 1/2013, se dio por vencido el préstamo por aplicación de una cláusula contractual reputada nula, deberían ser sobreseídos sin más trámite.

b) Los procesos en que, con posterioridad a la entrada en vigor de la Ley $1 / 2013$, se dio por vencido el préstamo por aplicación de una cláusula contractual reputada nula, y el incumplimiento del deudor no reúna los requisitos 
de gravedad y proporcionalidad antes expuestos, deberían ser igualmente sobreseídos.

c). Los procesos referidos en el apartado anterior, en que el incumplimiento del deudor revista la gravedad prevista en la LCCI, podrán continuar su tramitación.

d) Los autos de sobreseimiento dictados conforme a los apartados a) y b) anteriores no surtirán efecto de cosa juzgada respecto de una nueva demanda ejecutiva basada, no en el vencimiento anticipado por previsión contractual, sino en la aplicación de disposiciones legales (ATJUE de 3 de julio de 2019, asunto C-486/16). Solución que no pugna con el art. 552.3 LEC, puesto que no se trata de un segundo despacho de ejecución con fundamento en el mismo título, sino de ejecuciones basadas en diferentes títulos (el contrato, en el primer caso, y la ley en el segundo)".

Si el vencimiento anticipado se produce después, el prestatario-persona física, sea consumidor o no, será protegido por el art. 24 LCCI (la cláusula que hubiera será sustituida automáticamente por el régimen resolutorio previsto).

El incidente extraordinario de oposición que se articula para los procedimientos de ejecución en curso a la entrada en vigor de la Ley 1/2013, de 13 de mayo, previsto en la DT $3^{\text {a }}$ LCCI, sólo puede ser utilizado por quienes son prestatarios beneficiados por esta Ley, esto es consumidores, quienes son los que pueden oponer el carácter abusivo de una cláusula.

Por último, mientras no haya un cauce específico para formular quejas por parte de los potenciales prestatarios, prestatarios o garantes, sin distinción, habrá que presentarlas al Banco de España (DT $\left.5^{\circ} \mathrm{LCCI}\right)^{27}$. La Ley que en su día transponga la Directiva 2013/11/UE, de 21 de mayo de 2013, relativa a la resolución alternativa de litigios en materia de consumo, quizá quede reducida al ámbito subjetivo de los consumidores. En tal caso, los que no tienen la condición de consumidores tendrán que presentar sus reclamaciones al Banco de España.

\section{UNA ÚLTIMA CONSIDERACION}

La LCCI en cuanto al ámbito subjetivo no se debe entender tanto como una ampliación del concepto de consumidor sino más bien como una ampliación del ámbito de aplicación al extender la protección a materias que podrían estar excluidas sin incumplir por ello a la Directiva 2014/17/UE. No obstante, el mayor ámbito de aplicación es un tanto relativo al referirse sólo a los préstamos hipotecarios de inmuebles de uso residencial, quedando fuera los demás inmuebles. A esta misma conclusión se debe llegar, aunque susceptible de ser discutida en otro momento, cuando son préstamos cuya finalidad sea adquirir o conservar derechos de propiedad sobre terrenos o inmuebles construidos o por construir, siempre que el prestatario, el fiador o garante sea consumidor.

\footnotetext{
${ }^{27}$ La normativa catalana sobre la mediación obligatoria ha sido declarada inconstitucional por el TC en sentencia de 14 febrero 2019.
} 


\section{BIBLIOGRAFÍA}

ALBIEZ DOHRMANN, K. J. (2018), "Estudio comparado de la transposición de la Directiva 2013/17/UE del Parlamento y del Consejo Europeo, de 4 de febrero de 2014, sobre los contratos de crédito celebrados con consumidores para bienes inmuebles de uso residencial en algunos ordenamientos nacionales", Jornadas sobre la adaptación del Derecho español a la legislación y jurisprudencia en materia de créditos inmobiliarios, Registradores de España, Fundación Registral, pp. 39 y ss.

ALBIEZ DOHRMANN, K. J. (2018), “Algunas reflexiones básicas sobre el ámbito de aplicación de la futura regulación legal de los contratos de crédito inmobiliario", Derecho privado, responsabilidad y consumo, dir. PÉREZSERRABONA GONZÁLEZ, J. L., Aranzadi, pp. 71 y ss.

ALBIEZ DOHRMANN, K. J. (2018), "La protección de los empresarios en la Propuesta de Ley <<De impulso de la transparencia en la contratación predispuesta $>>$. Una solución a medias”, Revista Lex Mercatoria, nº 8, pp. 1 y ss.

ALBIEZ DOHRMANN, K. J. (2016), "La cláusula de autorización por el Banco del destino profesional de la vivienda residencial o habitual hipotecada (a propósito de la STS 23 diciembre 2015), Revista Lex Mercatoria, número 8, pp. 35 y ss.

ALVAREZ MORENO M $\mathrm{M}^{\mathrm{a}} \mathrm{T}$. (2015), La protección jurídica del consumidor en la contratación en general (Normas imperativas y pactos al respecto), Ed. Reus.

ARROYO AMAYUELAS, E. (2017), "La directiva 2014/17/UE sobre los contratos de crédito con consumidores para bienes de uso residencial”, Indret.

BERRROCAL LANZAROT, A. L. (2018). "Consideraciones generales en torno al proyecto de ley reguladora de los contratos de crédito inmobiliario”, Actualidad civil, n. 1 , pp. 1 y ss.

CÁMARA LAPUENTE, S. (2019), "La transparencia en la Ley 5/2019, de contratos de crédito inmobiliario. Primeros apuntes”, La Ley, versión 27/03/2019.

DOMÍNGUEZ LUELMO, A. (2018) "La vivienda habitual y otros inmuebles en garantía del cumplimiento de las obligaciones del prestatario”, Los contratos de crédito inmobiliario, dirs. ALBIEZ DOHRMANN, K. J. / MORENO-TORRES HERRERA, $\mathbf{M}^{\mathrm{a}}$ L., Aranzadi, pp. 947 y ss.

ESQUIROL JIMÉNEZ, V. (2015), "La nueva regulación de los créditos y préstamos hipotecarios en el Código de consumo de Cataluña”, RJC, pp. 743 y ss.

GARCÍA VICENTE, J. R. (2013), "La contratación con consumidores”, en Tratado de contratos, dir. BERCOVITZ RODRÍGUEZ-CANO, B., tomo II, $2^{\mathrm{a}}$ ed., Tirant lo Blanch, pp. 1649 y ss.

HABERSACK, M./ MAYER. C. (2015), “Die überschießende Umsetzung von Richtlinien”, Europäische Methodenlehre, ed. RIESENHUBER, K., $3^{\mathrm{a}}$ ed., De Gruyter, pp. 309 y ss.

LÓPEZ HERNÁNDEZ, C. V. (2018), "La regulación autonómica del crédito hipotecario: Ley 3/2016, de 9 de junio”, Los contratos de crédito inmobiliario, dirs. ALBIEZ DOHRMANN K. J./ MORENO- TORRES HERRERA, M ${ }^{a}$ L., Aranzadi, pp. 217 y ss.

NASARRE AZNAR, S./ SIMÓN MORENO, H. (2015), "Un paso más en la protección de los deudores hipotecarios de vivienda: La Directiva 2014/17/UE y la Reforma del Código de Consumo de Cataluña por Ley 20/2014”, $R D B B, \mathrm{n}^{0} 139$, 2015, pp. 11 y ss 
RODRÍGUEZ ACHÚTEGUI, E. (2017), “Algunas consideraciones sobre el anteproyecto de ley reguladora de contratos de crédito inmobiliario", Aranzadi Doctrinal, $\mathrm{n}^{\circ} 10$.

SÁENZ DE JUBERA HIGUERO, B. (2019), Los contratos de crédito inmobiliario tras la Ley 5/2019, de 15 de marzo, Tirant lo Blanch.

SÁNCHEZ RUIZ DE VALDIVIA, I. (2018), "La condición de consumidor/a o empresario/a en los contratos con doble (o simple) finalidad y los controles de abusividad (contenido) y transparencia en la contratación entre empresarios/as”, Derecho privado, responsabilidad y consumo, dir. PÉREZ-SERRABONA GONZÁLEZ J.L., Aranzadi, pp. 433.

VALERO FERNANDEZ-REYES, A. (2019), "La Ley de contratos de crédito inmobiliario: aspectos registrales y relacionados con la jurisprudencia del TJUE de 26 de marzo de 2019 sobre el vencimiento anticipado”, La Ley, 2019. 